\title{
Possible Mechanical Transmission of SARS-CoV-2 Causing COVID-19 by Insects: Infection, Prevention, Implications, and Control
}

\author{
Mubarak Ismail1, Abhishek Kumar Verma1, Adamu Abdulkadir'1, Avinash Kumar², \\ Dinesh Kumar Dhawan³, Kinjal Bolya1, Mayadhar Barik ${ }^{2 *}$
}

\footnotetext{
${ }^{1}$ Department of Life Sciences, Mewar University, Chittorgarh, India

${ }^{2}$ Department of Paramedical Sciences, Mewar University, Chittorgarh, India

${ }^{3}$ Department of Microbiology, Central University of Punjab, Bathinda, India

Email: ^mayadharbarik@gmail.com, ^dr.mayadhar@mewaruniversity.co.in
}

How to cite this paper: Ismail, M., Verma, A.K., Abdulkadir, A., Kumar, A., Dhawan, D.K., Bolya, K. and Barik, M. (2020) Possible Mechanical Transmission of SARS-CoV-2 Causing COVID-19 by Insects: Infection, Prevention, Implications, and Control. Open Journal of Medical Microbiology, 10, 89-101. https://doi.org/10.4236/ojmm.2020.102008

Received: May 26, 2020

Accepted: June 21, 2020

Published: June 24, 2020

Copyright $\odot 2020$ by author(s) and Scientific Research Publishing Inc. This work is licensed under the Creative Commons Attribution International License (CC BY 4.0).

http://creativecommons.org/licenses/by/4.0/ (c) () Open Access

\begin{abstract}
The new coronavirus called SARS-CoV-2 is a new type of virus named as COVID-19. Although, it has few similarities with pandemic flu viruses, the respiratory system and immune system are damaged through the viruses infected the population who has weakened immunity. SARS-CoV-2 spreads when people don't have the sign and symptoms. This virus COVID-19 appears to spread more easily than the flu, and asymptomatic transmission may account for a greater proportion of COVID-19's spreader over the World. In inundation of the current understanding, the roles of insect vectors are helping in the transmission of viral pathogens as well and the possible roles of some newly joined insects in the mechanical transmission of COVID-19. We also specifically provide the prevention and control methods related to contamination, disease burden, risk pattern in the family, near and dear to maintain the precision of social distancing and development of the immune system to fight against SARS-CoV-2.
\end{abstract}

\section{Keywords}

SARS-CoV-2, Insects, Prevention, Control, Mechanical Transmission

\section{Introduction}

Currently, there is high emergence of epidemic respiratory viral infections with the ability to cause diseases and mortality. Influenza viruses in 1918, 1957, and 1968 are the most significant pandemics of the $20^{\text {th }}$ Century [1]. In 2003 a global 
alert was issued for an emerging yet unknown illness known as a severe acute respiratory syndrome (SARS) caused by a novel coronavirus (SARS-CoV-2) [2] which caused substantial economic impact with roughly 8000 cases and 800 deaths in over 30 countries. Since then the world has experienced the emergence of several other viral respiratory pathogens including Middle East respiratory syndrome coronavirus (MERS-CoV), adenovirus-14, and virulent strains of influenza viruses. Soon after the discovery of SARS, new coronaviruses NL63 and HKU1 were identified [3] [4]. The novel severe acute respiratory syndrome coronavirus 2 (SARS-CoV-2) outbroken in Wuhan, China [5] in late 2019 and then spread globally by mid-May of 2020 has caused more than 4,500,927 confirmed cases and 302,066 deaths in 213 countries [6]. On March 11, 2020, the World Health Organization (WHO) declared the ongoing spread of SARS-CoV-2 a global pandemic [7]. The COVID-19 pandemic may represent the most significant public health emergency that the world has faced in a century.

Health care workers (HCWs) and nonetheless, coronaviruses have been implicated with reports of transmission related to environmental contamination [8]. Experimental evidence also suggests that SARS-COV-2 can be transmitted by aerosol but the role of insect in mechanical transmission and environmental contamination remains unclear [9] although many groups of insects are always in close contact with the patients as well as the environment in which these patients are isolated. The present study aimed to investigate the possibility of COVID-19 transmission by insects. Arboviral diseases (arthropod-borne viral) are caused by a wide variety of RNA viruses with a life cycle that requires both a host (birds or mammals) and a vector [10]. Human ecology and behavior are two factors that play a key role in the emergence or re-emergence of these infections [11]. There are at least 135 arboviruses that have been recognized to create human disease (Dash, Bhatia, Sunyoto, \& Mourya, 2013). Arboviral infections can range from asymptomatic to fatal disease. The clinical symptoms are commonly grouped as invasive neurological diseases, hemorrhagic fever, and systemic febrile illness [12]. Re-emerging and emerging pathogenic agents of zoonotic origin have become an important universal fear [13]. Arboviruses are a group of viruses that replicate in both their arthropod and vertebrate hosts. They are transmitted between vertebrates through the bite of blood-sucking arthropods. The vast majority of arboviruses belong to one of the five family's Togaviridae, Flaviviridae, Bunyaviridae, Reoviridae, and Rhabdoviridae [14]. We are trying to implement an effective public health measure (EPHMs) for understanding the modes of transmission of emerging infectious disease is a key factor. Due to the lack of the maximum evidence on SARS-CoV-2 transmission dynamics misleads to shift in isolation guidelines between airborne and droplet isolation precautions [15]. WHO, US CDC, and other public health authorities. Other emerging coronaviruses (e.g. SARS and MERS) have been suggested to have airborne transmission potential [16] in addition to more direct contact, and droplet transmission would be known better in this research article example 
with and evidenced-based.

\section{SARS-CoV-2 Mode of Transmission}

Coronavirus is animal-originated enveloped viruses with single-stranded, positive-sense RNA and a genome size of $26-32 \mathrm{~kb}$; they belong to the family Coronaviridae, order Nidovirales, genus Betacoronavirus [17]. Human coronaviruses 229E (HCoV-229E), NL63 (HCoV-NL63), OC43 (HCoV-OC43), HKU1, MERS-CoV, SARS-CoV, and the newest one SARS-CoV-2 or CoV-2019 or COVID-19 virus or novel corona virus-2019, are the seven types of human coronaviruses identified commonly among the infect people worldwide and cause respiratory infections in children and adults [18] [19].

Although, the origination of this disease is still unknown, very recently its outbreak located in Wuhan, China, in late 2019 with the high epidemic ability and human mortality rate (HMR) are higher. Now, it is a pandemic and affected more than 190 countries. It has been suggested that the COVID-19 virus transmission and evolution path occurred from bats to scaly anteaters (pangolins) and then to the human groups [5].

In general, respiratory virus infection can occur through contact (direct or indirect), droplet spray in short-range transmission, aerosol in long-range transmission (airborne transmission) [20] (Table 1). As with other respiratory

Table 1. Major accepted respiratory routes of transmission (RRT).

\begin{tabular}{|c|c|c|c|}
\hline $\begin{array}{c}\text { The pattern of } \\
\text { Transmission route } \\
\text { (PTR) }\end{array}$ & $\begin{array}{l}\text { Particles involved and } \\
\text { particle characteristics }\end{array}$ & $\begin{array}{c}\text { Characteristics/definition of } \\
\text { transmission }\end{array}$ & References \\
\hline Contact & & $\begin{array}{c}\text { Self-inoculation of mucous } \\
\text { membranes by contaminated hands. }\end{array}$ & {$[21]$} \\
\hline Direct & Deposited on persons. & $\begin{array}{l}\text { Virus transfer from one infected } \\
\text { person to another. }\end{array}$ & {$[22]$} \\
\hline Indirect & Deposited on objects. & $\begin{array}{l}\text { Virus transfer through contaminated } \\
\text { intermediate objects (fomites). }\end{array}$ & [23] \\
\hline \multirow[t]{3}{*}{ Airborne Droplets } & Droplets $(>5 \mu \mathrm{m})$ & Short-range transmission. & [20] \\
\hline & $\begin{array}{l}\text { Remain only shortly in } \\
\text { the air }(<17 \mathrm{~min})\end{array}$ & $\begin{array}{l}\text { Direct inoculation of naïve person } \\
\text { through coughing/sneezing/breathing } \\
\text { of an infected person. }\end{array}$ & \\
\hline & $\begin{array}{l}\text { Dispersed over short } \\
\text { distances }(<1 \mathrm{~m})\end{array}$ & $\begin{array}{l}\text { Deposition mainly on mucous } \\
\text { membranes and upper respiratory } \\
\text { tract. }\end{array}$ & \\
\hline \multirow[t]{3}{*}{ Aerosol Droplets } & $\begin{array}{l}\text { Aerosols, droplet nuclei } \\
\qquad(>5 \mu \mathrm{m})\end{array}$ & Long-range transmission (LRT) & {$[24]$} \\
\hline & $\begin{array}{c}\text { Remain in the air for an } \\
\text { almost infinite amount } \\
\text { of time }\end{array}$ & $\begin{array}{c}\text { Inhalation of aerosols in a repairable } \\
\text { size range (RSR) }\end{array}$ & \\
\hline & $\begin{array}{l}\text { Dispersed over long } \\
\text { distances }(>1 \mathrm{~m})\end{array}$ & $\begin{array}{l}\text { Deposition along the respiratory tract, } \\
\text { including the lower airways. }\end{array}$ & \\
\hline
\end{tabular}


pathogens, including flu and rhinovirus, the transmission is believed to occur through respiratory droplets from coughing and sneezing. Aerosol transmission is also possible in case of protracted exposure to elevated aerosol concentrations in closed spaces. Analysis of data related to the spread of SARS-CoV-2 seems to indicate that closer contact between the individuals is necessary.

COVID-19 is a new disease and we are still learning about how it spreads according to the US Centers for Disease Control and Prevention [25]. The virus is thought to spread mainly between people via respiratory droplets from an infected person's coughs and sneezes within about 6 feet. Despite that, some experts think that 6 feet (1.8 meters) are not enough [26]. Air Currents influence the movement of respiratory droplets. Larger respiratory droplets $(>5 \mu \mathrm{m})$ remain in the air for only a short time and travel only short distances, generally $<1$ $\mathrm{m}$ (less than 3.3 feet) [27] [28] [29]. Virus-laden small $(<5 \mu \mathrm{m})$ aerosolized droplets can remain in the air and travel long distances, $>1 \mathrm{~m}$ (more than 3.3 feet) [30].

Temperature and humidity modulate the viability of viruses by affecting the properties of viral surface proteins and lipid membranes [20]. Relative humidity (RH, or Saturation Ratio: the state of vapor equilibrium in room air) affects all infectious droplets with respiratory viruses, independent of their source (respiratory tract or aerosolized from any fluid) and location (in the air or settled on surfaces). Relative humidity, therefore, affects all transmission ways but has the most pronounced effect on airborne transmission. Transmission of these viruses takes place throughout the year Measurements of indoor humidity showed indoor vapor pressure of below $10 \mathrm{Mb}$ or indoor $\mathrm{RH}$ of below $24 \%$ in the winter. Hence, these show that the Transmission of these viruses takes place throughout the year in all types of weather conditions. 13.1 feet is seen as the maximum transmission distance of SARS-CoV-2 aerosol, in hospital settings, as such medical staff and other close contacts are at high risk for infection [31] (Figure 1).

This is true in a hospital setting and doesn't necessarily apply to other settings. In the context of COVID-19, when procedures or support treatments that generate aerosols are performed there may be possible airborne transmission; i.e., endotracheal intubation, bronchoscopy, open suctioning, administration of nebulized treatment, manual ventilation before intubation, turning the patient to the prone position, disconnecting the patient from the ventilator, non-invasive positive-pressure ventilation, tracheostomy, and cardiopulmonary resuscitation [23]. Information on the transmission reveled that, SARS-CoV-2 remained viable in aerosols for 3 hours on several environmental conditions (aerosols, plastic, stainless steel, copper, and cardboard) [24] despite the WHO notes that these findings need to be interpreted carefully in this experimental study because aerosols were generated using controlled laboratory. Further, the finding of COVID-19 virus in aerosol particles up to 3 hours does not reflect a clinical setting in which aerosol-generating procedures are performed-that is, this was an experimentally induced aerosol-generating procedure [23]. 


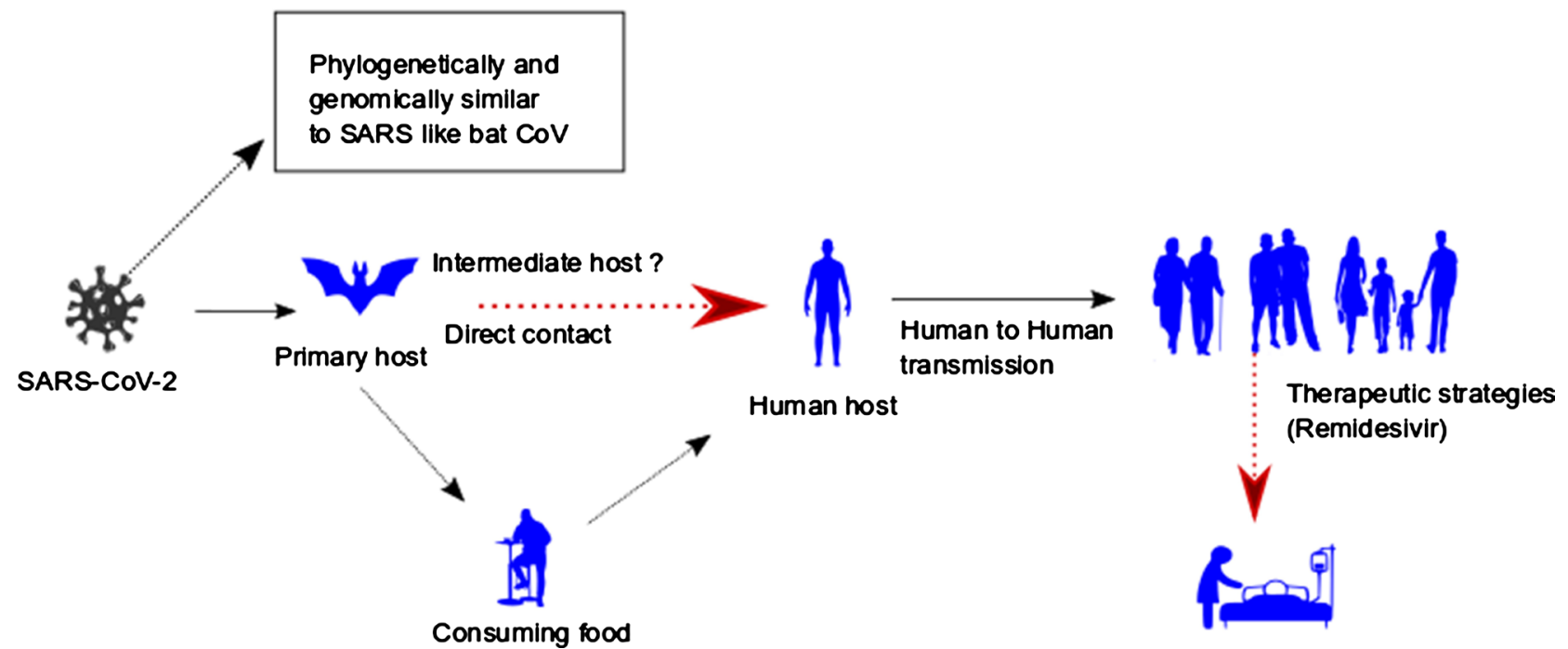

Figure 1. Structure of respiratory syndrome causing human coronavirus and Mode of Transmission.

The virus could spread by touching an object or surface with a virus present from an infected person, and then touching the mouth, nose, or eyes [32]. 76.5\% of all personal items sampled at the University of Nebraska Medical Center (UNMC) were determined to be positive for SARS-CoV-2 [7]. Although the virus titer was greatly reduced, viable SARS-CoV-2 was measured to last on plastic up to 2 - 3 days, stainless steel up to 2-3 days, cardboard up to 1 day, and copper up to 4 hours. There is a high positivity for floor swab samples, this might be due to gravity and airflow causing most virus droplets to float to the ground. There is also a $50 \%$ rate of positivity from the soles of the ICU medical staff shoes [32].

\section{Insects as Vehicles for Mechanical Transmission of Virus}

Arthropods are divided into class namely; insects, crustaceans, arachnids, and myriapods [32]. Insects consist of the most abundant known species of animals of all kinds which can exist as parasitic or freely living forms in nature. Parasitic arthropods often act as a vector in disease transmission by mainly feeding on the blood of animals and humans [33]. However, just because an arthropod feeds on a diseased host does not ensure that it can become infected, nor does it ensure that ingested pathogens can survive and develop. These arthropods transmit pathogens via the two methods.

Mechanical transmission is also called as the passive transmission. It involves the use of contaminated mouth-parts, legs, setae, or any other body parts of the arthropods in the transfer of the pathogens with no developmental change or multiplication of the pathogen on or in the arthropod. Hence, they only act as a transfer medium [21]. Cockroaches also act as the same to disease in their mouth, legs. Likewise, housefly can cause diarrhea and dysentery by transferring bacteria from infected human feces and contaminate food (Figure 1).

The active transmission is also called as the biological transmission. It is the most important type of transmission by arthropods. As the name implies, the 
pathogen must undergo some type of biological development in the body of the arthropod vector to complete its life cycle. There are four types of biological transmission [21]. 1) Propagative transmission occurs when the organism ingested with the blood meal undergoes simple multiplication in the body of the arthropod. Arboviruses, for example, replicate extensively in various tissues of mosquitos, flies, and ticks, and are transmitted to a new host in the salivary fluid of the arthropod when it takes a blood meal 2) Cyclopropagative transmission to multiplication, the pathogen undergoes the developmental cycle (changes from one stage to another) as well. The best example of a disease transmitted in this way is malaria, in which a single zygote may give rise to $>200,000$ sporozoites 3 ) Cyclodevelopmental transmission: in this type of transmission there is not multiplication but the pathogen undergoes developmental changes from one stage to another. 4) Vertical and direct transmission. Pathogens are transmitted from female parent to offspring via eggs. When the pathogens infect a developing egg termed as the "transovarial transmission". While in some cases the ovarian sheath and oviduct are infected in such case the eggs are also becomes infected as it passes through the cavity and is inseminated and this is termed as vertical transmission. A venereal transmission is also seen when a male mosquito becomes infected transovarially or vertically transfers the virus to uninfected female mosquitoes in the seminal fluid during copulation. The virus is seemingly attracted to the uninfected female arthropod through a chemo-tactic response to the salivary fluid injected into their bite wound.

\section{Transmission Process of COVID-19 by Insects}

The Coronavirus Disease initiates or appeared in the animal world before hitting humanity. These viruses can be transmitted by direct contact with an infected animal or by consuming meat or other products that did not pass through the appropriate processing. As for the insects, there is still no proof that they can or cannot carry the virus. This means that insects are potential virus carriers, and we should beware of them until scientists figure out the truth [34]. Most of the indoor insects are a possible carrier and as well may play a critical role in such disease transmission, for instance, tick bugs are mini dangerous pests as they are the most common carriers of encephalitis that killed over 150,000 people in 2015 alone! Scientists have found that causative agent of encephalitis and several other viruses can survive within the tick bug shell for over 13 years. During its long life, a tick bug can infect any animal or human. Both of them can later infect more individuals noninvasively and perhaps on and on again. Flies are associated with more than 60 diseases all over the world (Figure 2). They infect the food and skin of animals as well as humans. Filth flies are potential mechanical vectors of pathogens because they can transfer the disease-causing pathogen from their contaminated bodies to our food, eyes, noses, mouths as well as open wounds [35]. The fleas have been the major spreaders of the plague since ancient times to the middle ages. These microscopic parasites are very jumpy, which lets 

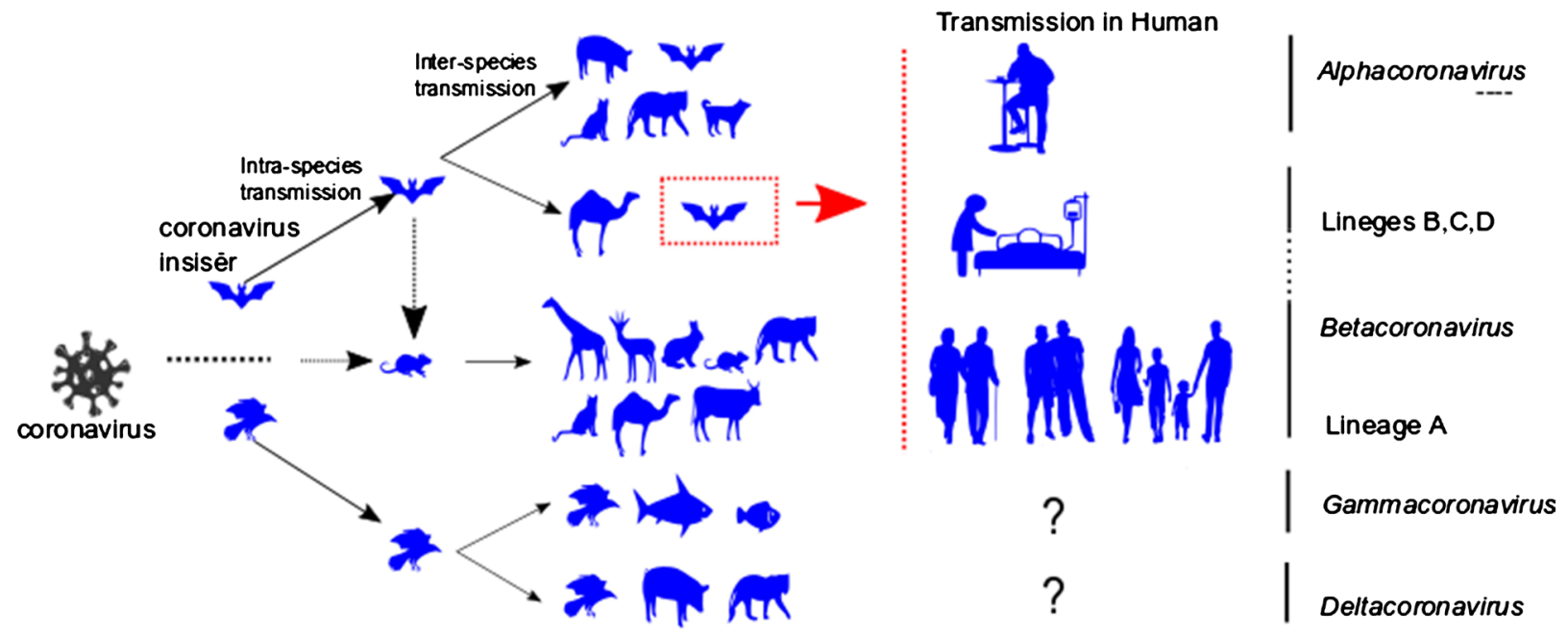

Figure 2. The key reservoirs and mode of transmission of coronaviruses (suspected reservoirs of SARS-CoV-2 are red encircled); only $\alpha$ and $\beta$ coronaviruses can infect humans, the consumption of infected animal as a source of food is the major cause of animal to human transmission of the virus and due to close contact with an infected person, the virus is further transmitted to healthy persons. The dotted black arrow shows the possibility of viral transfer from bat whereas the solid black arrow represents the confirmed transfer.

them travel very far and get into any place. They can infect domestic animals and people with oodles of pathogens, including helminthiasis, encephalitis, and many others. Of course, the middle ages are history, but there are no guarantees that fleas that feed on bats are not COVID-19 carriers.

On the other hand, cockroaches being nasty and nimble bugs are some of the most dangerous insects. They breed incredibly fast and eat any garbage that appears on their way. They are among the most notorious pests of premises, which not only contaminate food by leaving droppings and bacteria that can cause food poisoning but also they transmit bacteria, virus, fungi and other pathogenic microorganisms in infested areas [36]. Their nocturnal and filthy habits make them ideal carriers of various pathogenic microorganisms. They are tropical insects, so far numerous pathogenic bacteria, including Salmonella spp., Shigella spp., and $K$. pneumonia have been isolated from cockroaches. Besides, some parasites and fungi have been found in external surfaces or internal parts of the body of cockroaches [37]. Mosquitoes are famous carriers of encephalitis, malaria, and several others that are jeopardous as well as hardly treatable diseases. Every year, they infect over 200 million people in Asia, the Middle East, South America, and Africa. They can carry infected blood within their paunches and infect several people during their short lives.

There have been no reports of COVID-19 transmission by blood-sucking arthropods such as mosquitoes and lice [38]. However, major mechanical vectors of pathogens such as cockroaches and houseflies may be able to transmit the disease by contact with contaminated surfaces and even with the feces of infected individuals. In a limited number of case reports, the live virus has been reported in the feces of patients [23] [39] [40]. SARS-CoV-2, the virus that causes COVID-19, can be detected in the stool of up to $53.4 \%$ of 
COVID-19 patients [41] [42] [43]. Furthermore, despite the stool samples were still positive, about $23 \%$ of patients were no longer positive for the virus in respiratory samples [44]. Data from 98 COVID-19 patients showed viral shedding in the stool for nearly five weeks after respiratory samples were negative [45]. Another study reported that 30 days after initial infection, patients still shed the virus in the stool [30]. Even asymptomatic carriers may show elevated SARS-CoV-2 in the stool [42].

Although knowledge about the viability of SARS-CoV-2 is limited, the virus could remain viable in the environment for days, which could lead to fecal-oral transmission [46]. In a study to investigate SARS coronavirus carried by cockroaches, 15 cockroach surface swabs were tested by nested RT-PCR and only one uncertain positive result of the cockroach surface was found by nested RT-PCR [47]. The role and importance of this route have not yet been determined, but feces can be considered a possible important source of COVID-19 transmission. Therefore, any organism in contact with or feeding on human feces may play a role in COVID-19 transmission even after the organism is tested negative due to the prolonged viability of the virus in an environment. Therefore, the role of insects in the transmission of COVID-19 becomes important. These insects feed on a variety of food and come in contact with several human remnants ranging from food, feces, vomits, water droplets, catarrh, and transport them into the immediate environment or the neighboring environment. With the size of the SARS-CoV-2 virus and its presence in feces, droplets, and surface, there is a high possibility that insects can transmit the virus, which might course infection or prolong clinical trials.

\section{Prevention of Transmission and Control}

SARS, MERS, and now COVID-19 (coronavirus disease 2019) are zoonotic coronaviruses that have jumped the species barrier from their normal animal hosts to humans. This can happen through direct contact with an infected animal, as well as indirect contact or eating contaminated food. Zoonotic diseases are also very common and once transmitted to humans, they can spread through person-to-person contact as well, making proper handwashing and other preventative actions outlined by the CDC paramount to public safety [48]. SARS-CoV-2 infection may occur in both direct and indirect contact during respiration, toileting, and fomite contact [7].

WHO protocols for Covid-19 do not involve the possible transmission of the virus by insects that have close contact with the patients as well as the healthcare workers. There have been reports of COVID-19 transmission in prisons, hospitals, and other places where people live together for a long time from various Chinese provinces [23]. The proximity and close contact of people in such places and the potential for environmental contamination are important factors that can enhance transmission [23] [24]. Dealing with the COVID-19 virus and preventing its rapid and dangerous spread is a worldwide challenge that requires 
universal management.

This management involves personal hygiene, biological, physical, and less risk of chemical control. In this regard, maintaining appropriate environmental hygiene is of great importance especially bathrooms, toilets, and kitchens which has the highest infestation of cockroach and houseflies in the household environment [49]. It is also important to eliminate possible mechanical vectors such as cockroaches and flies in public places and residential homes. Control methods of these vectors include improved environmental sanitation. Installing stainless or plastic screens on doors, windows, and ventilators, covering food containers, and using poisoned baits, light traps, and sticky traps are some physical and mechanical control methods of these insects. Besides, medicinal plants such as Veratrum nigrum and eucalyptus are also very effective in repelling houseflies, mosquitoes, and cockroaches [40] [50] [51]. Biological control and application of parasitoids is a safe and environmentally friendly way of controlling these insects. Decaying materials, landfills, the areas around livestock and poultry farms, animal carcasses, garbage cans, and so on can attract houseflies and cockroaches to their lay eggs on them. Isolation centers should employ the use of nets to reduce possible contact with insects that might come in contact with respiratory droplets on their body or within their vicinity.

\section{Conclusion}

Coronavirus infection is a growing concern globally. Transmission management is now the primary option to prevent and control outbreaks of the disease in the absence of a vaccine. Most of the information generated on the possible transmission of COVID-19 is based on the already infected cases that are recorded. But enough efforts are not made to prevent and control possible transmission from other sources. Several kinds of research have shown the viability of SARS-CoV-2 in human pieces which have a longer duration than in respiratory droplets. The virus is also having a larger size compared to other families of coronavirus. This indicates that there is a possibility of transmission by an insect that can contact with patients or their droplets and feces. Several managements such as personal hygiene, biological, physical, and less risk chemical control should be employed.

\section{Acknowledgements}

A number of colleagues kindly advised us and provided information useful during the preparation of this paper, and we would like to thank namely, Muhammad Adamu Al-Botany and Sulaiman Sufyan. A special thanks to our parents and kwankwasiyya foundation.

\section{Conflicts of Interest}

The authors declare no conflicts of interest regarding the publication of this paper. 


\section{References}

[1] Kilbourne, E.D. (2006) Influenza Pandemics of the 20th Century. Emerging Infectious Diseases, 12, 9-14. https://doi.org/10.3201/eid1201.051254

[2] Shapiro, S.E. and Mccauley, L.A. (2004) SARS Update: Winter, 2003 to 2004. Aaohn Journal, 52, 199-203. https://doi.org/10.1177/216507990405200506

[3] van der Hoek, L., Pyrc, K., Jebbink, M.F., Vermeulen-Oost, W., Berkhout, R.J., Wolthers, K.C., Wertheim-van Dillen, P.M., Kaandorp, J., Spaargaren, J. and Berkhout, B. (2004) Identification of a New Human Coronavirus. Nature Medicine, 10, 368-373. https://doi.org/10.1038/nm1024

[4] Woo, P.C., Lau, S.K., Chu, C.M., Chan, K.H., Tsoi, H.W., Huang, Y., Wong, B.H., Poon, R.W., Cai, J.J., Luk, W.K. and Poon, L.L. (2005) Characterization and Complete Genome Sequence of a Novel Coronavirus, Coronavirus HKU1, from Patients with Pneumonia. Journal of Virology, 79, 884-895. https://doi.org/10.1128/JVI.79.2.884-895.2005

[5] Zhu, N., Zhang, D., Wang, W., Li, X., Yang, B., Song, J., Zhao, X., Huang, B., Shi, W., Lu, R. and Niu, P. (2020) A Novel Coronavirus from Patients with Pneumonia in China, 2019. New England Journal of Medicine. https://doi.org/10.1056/NEJMoa2001017

[6] Worldometer (2020) Coronavirus Cases. Worldometer.

[7] Sa Santarpia, J.L., Rivera, D.N., Herrera, V., Morwitzer, M.J., Creager, H., Santarpia, G.W., Crown, K.K., Brett-Major, D., Schnaubelt, E., Broadhurst, M.J. and Lawler, J.V. (2020) Transmission Potential of SARS-CoV-2 in Viral Shedding Observed at the University of Nebraska Medical Center.

https://doi.org/10.1101/2020.03.23.20039446

[8] Chowell, G., Abdirizak, F., Lee, S., Lee, J., Jung, E., Nishiura, H. and Viboud, C. (2015) Transmission Characteristics of MERS and SARS in the Healthcare Setting: A Comparative Study. BMC Medicine, 13, 210. https://doi.org/10.1186/s12916-015-0450-0

[9] Wang, D., Hu, B., Hu, C., Zhu, F., Liu, X., Zhang, J., Wang, B., Xiang, H., Cheng, Z., Xiong, Y. and Zhao, Y. (2020) Clinical Characteristics of 138 Hospitalized Patients with 2019 Novel Coronavirus-Infected Pneumonia in Wuhan, China. JAMA, 323, 1061-1069. https://doi.org/10.1001/jama.2020.1585

[10] Weaver, S.C. and Barrett, A.D. (2004) Transmission Cycles, Host Range, Evolution and Emergence of Arboviral Disease. Nature Reviews Microbiology, 2, 789-801. https://doi.org/10.1038/nrmicro1006

[11] Dehghani, R. and Kassiri, H. (2020) A Brief Review on the Possible Role of Houseflies and Cockroaches in the Mechanical Transmission of Coronavirus Disease 2019 (COVID-19). Archives of Clinical Infectious Diseases, 15, e102863. https://doi.org/10.5812/archcid.102863

[12] Dash, A.P., Bhatia, R., Sunyoto, T. and Mourya, D.T. (2013) Emerging and Re-Emerging Arboviral Diseases in Southeast Asia. Journal of Vector Borne Diseases, $50,77$.

[13] Mayer, S.V., Tesh, R.B. and Vasilakis, N. (2017) The Emergence of Arthropod-Borne Viral Diseases: A Global Prospective on Dengue, Chikungunya and Zika Fevers. Acta Tropica, 166, 155-163.

https://doi.org/10.1016/j.actatropica.2016.11.020

[14] Marchi, S., Trombetta, C.M. and Montomoli, E. (2018) Emerging and Re-Emerging Arboviral Diseases as a Global Health Problem. In: Public Health: Emerging and 
Re-Emerging Issues, IntechOpen, London, 25. https://doi.org/10.5772/intechopen.77382

[15] Agarwal, A., Parida, M. and Dash, P.K. (2017) Impact of Transmission Cycles and Vector Competence on Global Expansion and Emergence of Arboviruses. Reviews in Medical Virology, 27, e1941. https://doi.org/10.1002/rmv.1941

[16] Booth, T.F., Kournikakis, B., Bastien, N., Ho, J., Kobasa, D., Stadnyk, L., Li, Y., Spence, M., Paton, S., Henry, B. and Mederski, B. (2005) Detection of Airborne Severe Acute Respiratory Syndrome (SARS) Coronavirus and Environmental Contamination in SARS Outbreak Units. The Journal of Infectious Diseases, 191, 1472-1477. https://doi.org/10.1086/429634

[17] Farnoosh, G., Alishiri, G., Hosseini Zijoud, S.R., Dorostkar, R. and Jalali Farahani, A. (2020) Understanding the Severe Acute Respiratory Syndrome Coronavirus 2 (SARS-CoV-2) and Coronavirus Disease (COVID-19) Based on Available Evidence-A Narrative Review. Journal of Military Medicine, 22, 1-11.

[18] CDC (2020) Human Coronavirus Types. https://www.cdc.gov/coronavirus/types.html

[19] Fernstrom, A. and Goldblatt, M. (2013) Aerobiology and Its Role in the Transmission of Infectious Diseases. Journal of Pathogens, 2013, Article ID: 493960. https://doi.org/10.1155/2013/493960

[20] Moriyama, M., Hugentobler, W.J. and Iwasaki, A. (2020) Seasonality of Respiratory Viral Infections. Annual Review of Virology, 7. https://doi.org/10.1146/annurev-virology-012420-022445

[21] Barclay, L. and Esther, N. (2020) COVID-19: What Do We Know about Transmission Routes and Surface Survival? https://www.medscape.org/viewarticle/927708

[22] Kwok, Y.L.A., Gralton, J. and McLaws, M.L. (2015) Face Touching: A Frequent Habit That Has Implications for Hand Hygiene. American Journal of Infection Control, 43, 112-114. https://doi.org/10.1016/j.ajic.2014.10.015

[23] World Health Organization (2020) Modes of Transmission of Virus Causing COVID-19: Implications for IPC Precaution Recommendations: Scientific Brief, 27 March 2020 (No. WHO/2019-nCoV/Sci_Brief/Transmission_modes/2020.1).

[24] van Doremalen, N., Bushmaker, T., Morris, D.H., Holbrook, M.G., Gamble, A., Williamson, B.N., Tamin, A., Harcourt, J.L., Thornburg, N.J., Gerber, S.I. and Lloyd-Smith, J.O. (2020) Aerosol and Surface Stability of SARS-CoV-2 as Compared with SARS-CoV-1. New England Journal of Medicine, 382, 1564-1567. https://doi.org/10.1056/NEJMc2004973

[25] 25CDC (2020) CDC Microsite-Coronavirus Disease 2019. https://www.cdc.gov/coronavirus/2019-ncov/index.html

[26] Letzter, R. (2020) Is 6 Feet Enough Space for Social Distancing? Live Science. https://www.livescience.com/coronavirus-six-feet-enough-social-distancing.html

[27] Kutter, J.S., Spronken, M.I., Fraaij, P.L., Fouchier, R.A. and Herfst, S. (2018) Transmission Routes of Respiratory Viruses among Humans. Current Opinion in Virology, 28, 142-151. https://doi.org/10.1016/j.coviro.2018.01.001

[28] Lu, J., Gu, J., Li, K., Xu, C., Su, W., Lai, Z., Zhou, D., Yu, C., Xu, B. and Yang, Z. (2020) COVID-19 Outbreak Associated with Air Conditioning in Restaurant, Guangzhou, China, 2020. Emerging Infectious Diseases, 26. https://doi.org/10.3201/eid2607.200764

[29] Pica, N. and Bouvier, N.M. (2012) Environmental Factors Affecting the Transmis- 
sion of Respiratory Viruses. Current Opinion in Virology, 2, 90-95. https://doi.org/10.1016/j.coviro.2011.12.003

[30] Yeo, C., Kaushal, S. and Yeo, D. (2020) Enteric Involvement of Coronaviruses: Is Faecal-Oral Transmission of SARS-CoV-2 Possible? The Lancet Gastroenterology \& Hepatology, 5, 335-337. https://doi.org/10.1016/S2468-1253(20)30048-0

[31] Guo, Z.D., Wang, Z.Y., Zhang, S.F., Li, X., Li, L., Li, C., Cui, Y., Fu, R.B., Dong, Y.Z., Chi, X.Y. and Zhang, M.Y. (2020) Aerosol and Surface Distribution of Severe Acute Respiratory Syndrome Coronavirus 2 in Hospital Wards, Wuhan, China, 2020. Emerging Infectious Diseases, 26. https://doi.org/10.3201/eid2607.200885

[32] Eldridge, B.F. and Edman, J.D. (2012) Medical Entomology: A Textbook on Public Health and Veterinary Problems Caused by Arthropods. Springer Science \& Business Media, Berlin.

[33] Zurek, L. and Schal, C. (2004) Evaluation of the German Cockroach (Blattella germanica) as a Vector for Verotoxigenic Escherichia coli F18 in Confined Swine Production. Veterinary Microbiology, 101, 263-267.

https://doi.org/10.1016/j.vetmic.2004.04.011

[34] Team, S. (2020) Insects and COVID-19: 5 Possible Coronavirus Carriers. https://scoopempire.com/insects-and-covid-19-5-possible-coronavirus-carriers

[35] Thyssen, P.J., Moretti, T.D.C., Ueta, M.T. and Ribeiro, O.B. (2004) The Role of Insects (Blattodea, Diptera, and Hymenoptera) as Possible Mechanical Vectors of Helminths in the Domiciliary and Peridomiciliary Environment. Cadernos de Saude Publica, 20, 1096-1102. https://doi.org/10.1590/S0102-311X2004000400025

[36] Gore, J.C. and Schal, C. (2007) Cockroach Allergen Biology and Mitigation in the Indoor Environment. Annual Review of Entomology, 52, 439-463. https://doi.org/10.1146/annurev.ento.52.110405.091313

[37] Cotton, M.F., Wasserman, E., Pieper, C.H., Theron, D.C., Van Tubbergh, D., Campbell, G., Fang, F.C. and Barnes, J. (2000) Invasive Disease Due to Extended Spectrum Beta-Lactamase-Producing Klebsiella pneumoniae in a Neonatal Unit: The Possible Role of Cockroaches. Journal of Hospital Infection, 44, 13-17. https://doi.org/10.1053/jhin.1999.0650

[38] CDC (2020) How Coronavirus Spreads. https://www.cdc.gov/coronavirus/2019-ncov/prevent-getting-sick/how-covid-sprea ds.html?CDC_AA_refVal=https\%3A\%2F\%2Fwww.cdc.gov\%2Fcoronavirus\%2F201 9-ncov\%2Fprepare\%2Ftransmission.html

[39] Aylward, B. and Liang, W. (2020) Report of the WHO-China Joint Mission on Coronavirus Disease 2019 (COVID-19). The WHO-China Joint Mission on Coronavirus Disease 2019, 2019(February), 16-24.

https://www.who.int/docs/default-source/coronaviruse/who-china-joint-mission-o n-covid-19-final-report.pdf

[40] Khan, M.A.H.N.A. (2015) Important Vector-Borne Diseases with Their Zoonotic Potential: Present Situation and Future Perspective. Bangladesh Journal of Veterinary Medicine, 13, 1-14. https://doi.org/10.3329/bjvm.v13i2.26614

[41] Tang, A., Tong, Z.D., Wang, H.L., Dai, Y.X., Li, K.F., Liu, J.N., Wu, W.J., Yuan, C., Yu, M.L., Li, P. and Yan, J.B. (2020) Early Release-Detection of Novel Coronavirus By RT-PCR in Stool Specimen from Asymptomatic Child, China. https://doi.org/10.3201/eid2606.20.0301

[42] Xie, C., Jiang, L., Huang, G., Pu, H., Gong, B., Lin, H., Ma, S., Chen, X., Long, B., Si, G. and Yu, H. (2020) Comparison of Different Samples for 2019 Novel Coronavirus Detection by Nucleic Acid Amplification Tests. International Journal of Infectious 
Diseases. https://doi.org/10.1016/j.ijid.2020.02.050

[43] Young, B.E., Ong, S.W.X., Kalimuddin, S., Low, J.G., Tan, S.Y., Loh, J., Ng, O.T., Marimuthu, K., Ang, L.W., Mak, T.M. and Lau, S.K. (2020) Epidemiologic Features and Clinical Course of Patients Infected with SARS-CoV-2 in Singapore. JAMA, 323, 1488-1494. https://doi.org/10.1001/jama.2020.3204

[44] Xiao, F., Tang, M., Zheng, X., Liu, Y., Li, X. and Shan, H. (2020) Evidence for Gastrointestinal Infection of SARS-CoV-2. Gastroenterology, 158, 1831-1833. https://doi.org/10.1053/j.gastro.2020.02.055

[45] Wu, Y., Guo, C., Tang, L., Hong, Z., Zhou, J., Dong, X., Yin, H., Xiao, Q., Tang, Y., $\mathrm{Qu}, \mathrm{X}$. and Kuang, L. (2020) Prolonged Presence of SARS-CoV-2 Viral RNA in Faecal Samples. The Lancet Gastroenterology \& Hepatology, 5, 434-435. https://doi.org/10.1016/S2468-1253(20)30083-2

[46] Zhang, J., Wang, S. and Xue, Y. (2020) Fecal Specimen Diagnosis 2019 Novel Coronavirus-Infected Pneumonia. Journal of Medical Virology, 92, 680-682. https://doi.org/10.1002/jmv.25742

[47] Zhao, G.P. (2007) SARS Molecular Epidemiology: A Chinese Fairy Tale of Controlling an Emerging Zoonotic Disease in the Genomics Era. Philosophical Transactions of the Royal Society B: Biological Sciences, 362, 1063-1081. https://doi.org/10.1098/rstb.2007.2034

[48] Parada, J. (2020) Is Coronavirus Transmitted by Pests? https://www.pestworld.org/news-hub/pest-health-hub/is-coronavirus-transmitted-b y-pests

[49] Nasirian, H. (2017) Infestation of Cockroaches (Insecta: Blattaria) in the Human Dwelling Environments: A Systematic Review and Meta-Analysis. Acta Tropica, 167, 86-98. https://doi.org/10.1016/j.actatropica.2016.12.019

[50] Alzogaray, R.A., Lucia, A., Zerba, E.N. and Masuh, H.M. (2011) Insecticidal Activity of Essential Oils from Eleven Eucalyptus spp. and Two Hybrids: Lethal and Sublethal Effects of Their Major Components on Blattella germanica. Journal of Economic Entomology, 104, 595-600. https://doi.org/10.1603/EC10045

[51] Cai, X., Li, Q., Xiao, L., Lu, H., Tang, J., Huang, J. and Yuan, J. (2018) Insecticidal and Acetylcholinesterase Inhibition Activity of Veratrum nigrum Alkaloidal Extract against the German Cockroach (Blattella germanica). Journal of Arthropod-Borne Diseases, 12, 414. https://doi.org/10.18502/jad.v12i4.361 